\title{
Bioaccessibility and speciation of arsenic in children's diets and health risk assessment
} of an endemic area in Bangladesh

Mohammad Mahmudur Rahman ${ }^{1,2 *}$, Mohammad Alauddin ${ }^{3}$, Sarah T. Alauddin ${ }^{3}$, Abu Bakkar Siddique $^{1,2,4}$, Md Rashidul Islam ${ }^{1,2}$, Gabriella Agosta ${ }^{3}$, Debapriya Mondal ${ }^{5}$ and Ravi Naidu ${ }^{1,2}$

${ }^{1}$ Global Centre for Environmental Remediation (GCER), Faculty of Science, The University of Newcastle, Callaghan Campus, Newcastle, NSW 2308, Australia

${ }^{2}$ Cooperative Research Centre for Contamination Assessment and Remediation of the Environment (CRC-CARE), ATC Building, The University of Newcastle, NSW 2308, Australia

${ }^{3}$ Department of Chemistry, Wagner College, Staten Island, NY 10301, USA

${ }^{4}$ Department of Agriculture, Noakhali Science and Technology University, Noakhali 3814, Bangladesh

${ }^{5}$ School of Science, Engineering \& Environment, University of Salford, Salford, M5 4WT, UK

*Corresponding author. Email: mahmud.rahman@ @ewcastle.edu.au

\section{Abstract}

This study determines the bioaccessibility of toxic and carcinogenic arsenic (As) in composite food samples and evaluates potential exposure from food intake in Bangladesh children. Total As (tAs), inorganic As (iAs) and bioaccessible As (BAs) in food composite samples consumed by children were compared between an exposed and a control group (based on As in drinking water). Total As concentrations in composite food samples of children exposed to mean As level of $331 \mu \mathrm{g} / \mathrm{l}$ in drinking and cooking water ranged from 586 to $1975 \mu \mathrm{g} / \mathrm{kg}$, dry weight over 76 to $90 \mu \mathrm{g} / \mathrm{kg}$ in the unexposed group. Average iAs in food composites was 
73.9\% (range: 49.3 to $90.8 \%$ ). The fraction of BAs using gastric and gastrointestinal phases was $91 \pm 13 \%$ and $98 \pm 11 \%$, respectively. Daily intake of iAs in exposed group ranged from 0.41 to $6.38 \mu \mathrm{g}$ per $\mathrm{kg}$ body weight (BW), which was much higher than the unexposed group (0.08-0.15 $\mu \mathrm{g}$ per $\mathrm{kg} \mathrm{BW})$. High iAs content and BAs in composite food samples indicated elevated risk to exposed children. Further research should include both adult and children using larger sample size to determine overall As exposure from food intake in Bangladesh, attention must be given to lowering of As in food.

\section{Graphical Abstract}
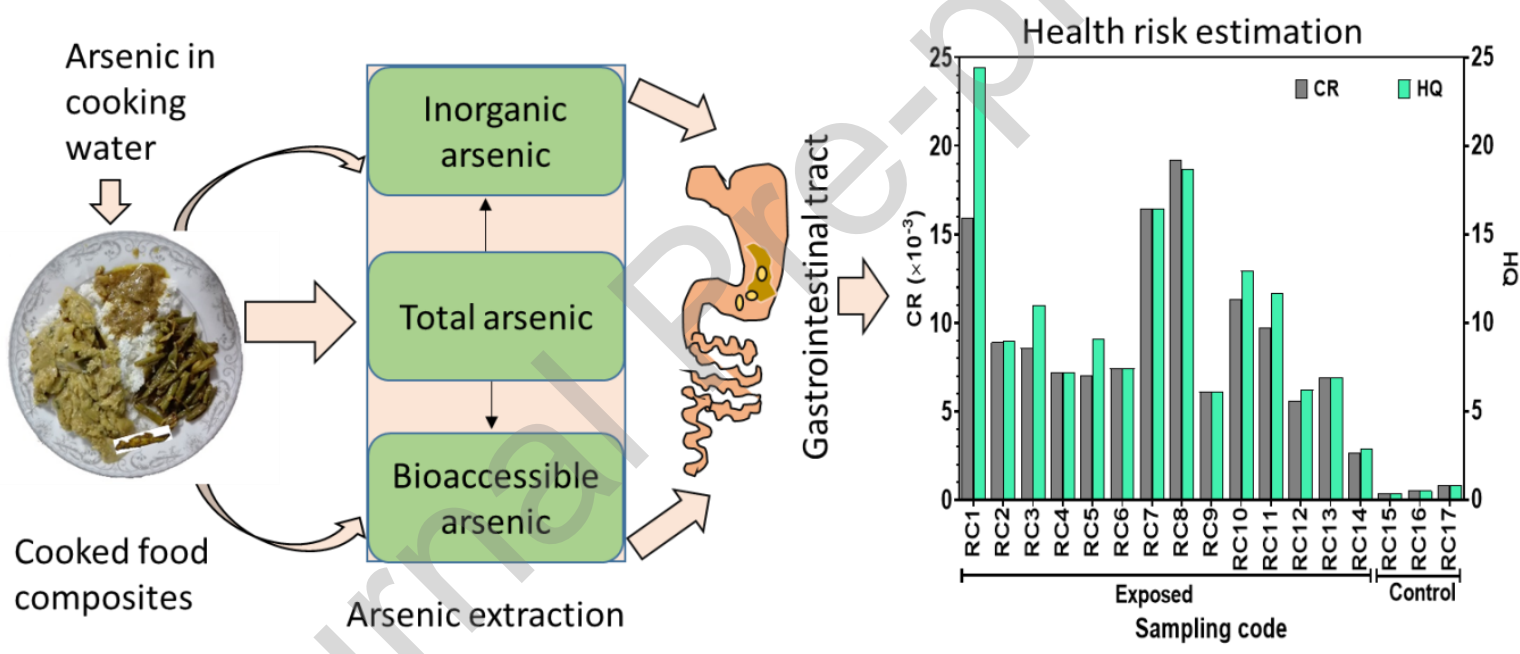

Keywords: Arsenic; Children; Food composites; Arsenic speciation; Arsenic bioaccessibility; Health risk.

\section{Introduction}

Human health risk assessment of trace elements, specifically arsenic (As) in food has received considerable attention in recent years because of food safety concerns (Antoniadis et al., 2017; Antoniadis et al., 2019). Health risk assessment of trace elements including As and its effects on plants and humans is crucial for effective regulatory guidelines. A recent study 
explored the transfer of the trace elements from soil to humans, emphasising that the human health risk assessment is a global one. This is due to their possible transfer through the food chain to people and is considered to be the main exposure route (Antoniadis et al., 2019). Arsenic is a carcinogen that has been detected in the groundwaters of Bangladesh, used both for drinking and cooking. Chakraborti et al. (2010) reported $27.2 \%$ and $42.1 \%$ of the 52,202 water samples analysed in Bangladesh had concentrations above 50 and $10 \mu \mathrm{g} / \mathrm{l}$, respectively. In addition to drinking water, people from the As-endemic areas in Bangladesh are significantly exposed to As through their daily diet (Rahman et al., 2011; Rahman et al., 2013; Rahman et al., 2009). The risk posed by rice based diet has been well reported (Carbonell-Barrachina et al., 2012; Islam et al., 2017c; Signes-Pastor et al., 2016) since rice is consumed in large quantities in Bangladesh. Its people usually consume more than $170 \mathrm{~kg}$ per capita per annum compared to the world average of $57 \mathrm{~kg}$ per capita per annum (Shew et al., 2019).

Average As content in the uncooked and cooked rice samples collected from households of Nawabganj district in Bangladesh was found to be $340 \mu \mathrm{g} / \mathrm{kg}$ and $460 \mu \mathrm{g} / \mathrm{kg}$, respectively (Ohno et al., 2007) indicating a rising As concentration in cooking whereas average As concentration in cooked rice $(139 \mu \mathrm{g} / \mathrm{kg})$ was lower than uncooked rice (153 $\mu \mathrm{g} / \mathrm{kg}$ ) in paired samples collected from households in the Noakhali district of Bangladesh (Rahman et al., 2011). Concentration of As may vary between uncooked and cooked rice, depending on the rice variety, As in raw rice, As in cooking water and process of cooking (Bae et al., 2002; Laparra et al., 2005; Mwale et al., 2018). A recent study reported that transfer of As from water to rice grains was influenced by the increasing concentration of As in water and rice type; concentrations of $84-105 \mu \mathrm{g} / \mathrm{L}$ in cooking water significantly increased As concentration (24-337\%, and $114 \%$ from sunned and parboiled rice, respectively) in 
cooked rice (Chowdhury et al., 2020). (Sengupta et al., 2006) found that the traditional cooking procedure commonly used in Bangladesh (whereby rice is washed with water until clear and excess water is discarded after cooking) can remove up to $57 \%$ of rice As. In a study conducted in the Monohordi and Munshiganj districts of Bangladesh, the average As content reported in cooked rice and cooked vegetables were $358 \mu \mathrm{g} / \mathrm{kg}$ and $333 \mu \mathrm{g} / \mathrm{kg}$, respectively (Smith et al., 2006). Hence, having cooked rice as a mainstay of the diet can be an important route of As exposure.

Infant and young children are most susceptible to As toxicity, although arsenical symptoms in children are rare except when they are exposed to very high concentrations of As or suffer from malnutrition (Rahman et al., 2001). Chronic exposure to As pose high health risks including neurobehavioural problems and decreased intellectual function in children (von Ehrenstein et al., 2007; Wasserman et al., 2004). In a study from Mexico the total As (tAs) and inorganic As (iAs) concentrations in children's diets ranged from 50 to $1150 \mu \mathrm{g} / \mathrm{kg}$, and 23 to $88 \mu \mathrm{g} / \mathrm{kg}$, dry weight (DW), respectively and daily intake of tAs and iAs ranged from 0.15 to $10.49 \mu \mathrm{g}$ per $\mathrm{kg} \mathrm{BW}$ and from 0.06 to $1.11 \mu \mathrm{g}$ per $\mathrm{kg} \mathrm{BW}$, respectively (García-Rico et al., 2012). In one study from Bangladesh, 2-5 yrs and 6-10 yrs age groups were more exposed to As due to rice consumption (Islam et al., 2017b). These results are alarming considering the higher risk of children being exposed to As through the food they eat.

In characterisation of As exposure and risk from food intake both in adults and children, one aspect that has recieved increased attention is the bioaccessibility of As (BAs) in consumed food (Laparra et al., 2005). Various studies have estimated the BAs in uncooked food (Signes-Pastor et al., 2012; Trenary et al., 2012) including shrimp, radish, mushroom, etc. (Chi et al., 2018; Hu et al., 2019; Koch et al., 2013) while other studies concentrated on 
raw and cooked rice (Laparra et al., 2005; Zhuang et al., 2016). A few studies investigated the BAs through simulated gastric phase (GP) and gastrointestinal phase (GIP) digestions (Llorente-Mirandes et al., 2016; Zhuang et al., 2016). The BAs of GP and GIP in raw rice and cooked rice varied from 36-102\% and 72-96\% respectively (He et al., 2012; Signes-Pastor et al., 2012; Zhuang et al., 2016). While health risk assessments based on the evaluation of BAs using different in-vitro assay for individual food items, whether raw or cooked have been reported (Laparra et al., 2005; Llorente-Mirandes et al., 2016; Zhuang et al., 2016), As speciation and bioaccessibility in food composites using both GP and GIP are limited. Furthermore, estimates of children's exposure to As in based on bioavailability of As in a composite diet are rare. To the best of our knowledge, no study has determined the concentrations of tAs, iAs and BAs in cooked food composites consumed by children in endemic areas which can provide an accurate estimate of As intake, exposure, and risks in children.

In this communication, for the first time we report As exposure in children from diet (lunch and dinner) comprising cooked rice, vegetables and pulses (which are the most commonly consumed foods by Bangladeshi people) from two As-contaminated villages in Bangladesh. The aim of this study is to determine tAs, iAs and BAs in the children's diet in As-endemic areas of Bangladesh to estimate the health risks for children.

\section{Materials and methods}

\subsection{Sample collection and preparation}

All the reagents used in this study were of analytical grade. The details of chemicals and reagents are given in the Supplementray Information (SI). For this study, a total of 14 diet samples from lunch and dinner menus were collected in 2018 from 14 households in two As- 
contaminated villages (Shahpur and Sursoi), which are located in Chandpur district of Bangladesh. It is worth noting that Chandpur was reported to be a severely As-contaminated area with $95.7 \%$ and $92.6 \%$ groundwater samples $(n=1165)$ having As above $10 \mu \mathrm{g} / \mathrm{L}$, the WHO provisional guideline value and $50 \mu \mathrm{g} / \mathrm{L}$, the Bangladesh standard value of As in drinking water, respectively (Chakraborti et al., 2010). Usually in these areas, lunch and dinner comprise of cooked rice, fish curry with different vegetables and lentil soup (locally known as dal). Households with at least two children were selected at random. Details of ethical approval are presented in SI. Altogether 31 children were selected from these two contaminated villages ( 9 boys and 8 girls from Shahpur and 7 boys and 7 girls from Sursoi) for this study (denoted as exposed group) and their food portion sizes were weighted for lunch and dinner to determine their daily dietary intake rates. For these 31 exposed children (16 boys and 15 girls) age, body weight as well as daily amount of food consumption (rice, curry and dal) was determined. The average age and weight of these children were 8.3 yrs (range 2 $15 \mathrm{yrs}$ ) and $26 \mathrm{~kg}$ (range $10-56 \mathrm{~kg}$ ), respectively. The average daily food consumption (fresh wt.) was $304 \mathrm{~g}$ (range: $85-563 \mathrm{~g}$ ). For the sake of comparison, diet samples of 4 children were also collected from Bhelanagar (denoted as unexposed group) which is situated in the Narsingdi Municipality where As-safe drinking water supply was available through a pipeline.

Food samples were collected from a plate (duplicate portion) when it was being served to children. The separately cooked rice, curry and dal were mixed and homogenised properly to create a composite sample. The mixed food samples were stored in zip-lock bags and stored in an ice box with ice and transported to the laboratory and then kept refrigerated until processing. These samples were dried in an oven at $65^{\circ} \mathrm{C}$ for $72 \mathrm{~h}$. The dried samples were again homogenised by grinding them. The samples were stored in zip-log bags. We also collected cooking and drinking water samples from both exposed and unexposed groups. 
Water samples from both these groups were collected in plastic bottle (pre-washed with 1:1 nitric acid) and preserved with $0.1 \%$ (v/v) nitric acid. The samples were subsequently transported to the University of Newcastle by courier under strict biosecurity protocol.

For tAs determination, the samples were digested using microwave acid digestion system that was employed by Islam et al. (2017c). The digests were diluted to $10 \mathrm{~mL}$ using $0.1 \% \mathrm{HNO}_{3}$ and passed through a $0.45 \mu \mathrm{m}$ syringe filter for the determination of tAs in the diet samples and water samples using inductively coupled plasma mass spectroscopy (ICPMS, PerkinElmer, NexION 350, USA).

Arsenic speciation analysis for inorganic As - sum of arsenite (AsIII), and arsenate (AsV), monomethylarsonic acid (MMA) and dimethyl arsinic acid (DMA) was carried out following the method of Signes-Pastor et al. (2016). Details of the procedure have been discussed in our previous publication (Islam et al., 2017c). High performance liquid chromatography (HPLC, Agilent 1200) coupled with ICP-MS (Agilent 7900) was used for As speciation analysis.

\subsection{In-vitro BAs assay}

Physiologically-based extraction test (PBET) is one of the most practical and feasible in-vitro methods to determine metal bioaccessibility. The method was adopted from the previously described studies (Kafaoglu et al., 2016; Llorente-Mirandes et al., 2016; Zhuang et al., 2016). Details procedure are given in SI. The prepared samples were anayzed using ICPMS for bioaccessible As.

The BAs (\%) was calculated according to the following equation.

$$
\text { BAs }(\%)=\frac{\text { Bioaccessible As concentration in food composite }}{\text { Total As concentration in food composite }} \times 100
$$




\subsection{Quality control}

Standard reference material (SRM 1568b rice flour) obtained from the National Institute of Standard and Technology (NIST), USA was used to validate the analysis. Concentration of total As in SRM rice flour (1568b) was 266 $\pm 11(\mathrm{n}=6) \mu \mathrm{g} / \mathrm{kg}$, indicating 93\% recovery (certified value of $285 \pm 14 \mu \mathrm{g} / \mathrm{kg}$ ). Blanks, duplicates and calibration check verification $(\mathrm{CCV})$ samples were included. The mean variation between duplicate samples $(n=12)$ was $2.8 \%(0.5-7.1 \%)$ and the recoveries for CCVs $(n=5)$ amounted to $103 \%(99-$ $105 \%$ ). In addition, we determined the accuracy of the As speciation method using SRM rice flour. The certified values for DMA, MMA and iAs in SRM rice flour were $180 \pm 12 \mu \mathrm{g} / \mathrm{kg}$, $11.6 \pm 3.5 \mu \mathrm{g} / \mathrm{kg}$ and $92 \pm 10 \mu \mathrm{g} / \mathrm{kg}$, respectively. The analytical results $(\mathrm{n}=5)$ for As speciation indicated that the values for DMA, MMA and iAs were $162 \pm 14 \mu \mathrm{g} / \mathrm{kg}, 8.2 \pm 3.1$ $\mu \mathrm{g} / \mathrm{kg}$ and $83 \pm 8 \mu \mathrm{g} / \mathrm{kg}$, respectively. Thus, recoveries for DMA, MMA and iAs were 90\%, $70.7 \%$ and $90.2 \%$, respectively.

\subsection{Statistical analysis}

Data were analysed and represented graphically using statistical software JMP version 14, IBM SPSS version 25, Microsoft Excel 2013, and Graph Pad Prism 8. Confidence level from $95 \%$ was considered for all statistical analyses.

\subsection{Risk assessment}

To evaluate the potential exposure of children to As, we evaluated the established daily dietary intake (EDDI) of As, hazard quotient (HQ) and cancer risk (CR) from cooked food using the following equations:

$$
\mathrm{EDDI}=\frac{\mathrm{FC} \times \mathrm{iAs} \times \% \mathrm{BAs} \times \mathrm{ED} \times \mathrm{EF}}{\mathrm{BW} \times \mathrm{AT}}
$$




$$
\begin{gathered}
\mathrm{HQ}=\frac{\mathrm{EDDI}}{\mathrm{RfD}} \text { and } \\
\mathrm{CR}=\mathrm{EDDI} \times \mathrm{CSF}
\end{gathered}
$$

Where, FC is cooked food consumption (g/day, fresh weight, FW); iAs is the concentration of the inorganic As in food component ( $\mu \mathrm{g} / \mathrm{kg}$ using FW); BAs is bioaccessibility of As through GIP tract (\%); BW stands for body weight, $(\mathrm{kg})$ of respective children; ED represents exposure duration (years) of the children taking into consideration their respective ages; EF is exposure frequency (365 days per year); AT represents average lifetime (365 days per year $\times$ number of exposure years); CSF is cancer slope factor (1.5 mg/kg per day); and RfD is oral reference dose $\left(3 \times 10^{-4} \mathrm{mg} / \mathrm{kg}\right.$ per day for As), as suggested by USEPA (IRIS 2013). In the case of $\mathrm{HQ}<1$, non-carcinogenic risks are not considered but for $\mathrm{HQ}>1$, there may be adverse health effects arising from exposure (Abtahi et al., 2017; Shibata et al., 2016; Zhuang et al., 2016). In terms of carcinogenic risk assessment, if $\mathrm{CR}<10^{-6}$, the increased cancer risk is deemed to be negligible, and $>10^{-6}$ a departure from negligible risk, $\mathrm{CR}>10^{-4}$ is considered to be an unacceptable increased cancer risk (Fakhri et al., 2018; Shibata et al., 2016).

\section{Results and discussion}

\subsection{Total As in diets}

Mean As in cooking and drinking water $(\mathrm{n}=5)$ for the exposed group was $331 \mu \mathrm{g} / \mathrm{l}$ (range: 88 - $720 \mu \mathrm{g} / \mathrm{l}$ ) whereas As concentration in cooking and drinking water (supply tap water, $n=2)$ of the control group was $<1 \mu \mathrm{g} / 1$. The concentration of tAs, iAs and BAs (\%) in the composite food samples are summarized in Table 1. The mean and range of As in food (dry wt.) were $1072 \mu \mathrm{g} / \mathrm{kg}$ and $586-1975 \mu \mathrm{g} / \mathrm{kg}$ for the exposed group, respectively. Considering that on average the moisture content was $80 \%$ in cooked composite food in this 
study, the mean and range of As in food (fresh wt.) were $214 \mu \mathrm{g} / \mathrm{kg}$ and $117-395 \mu \mathrm{g} / \mathrm{kg}$, respectively. The tAs concentrations (mean and range) in composite food samples (dry wt.) for the control group were $85 \mu \mathrm{g} / \mathrm{kg}$ and $76-90 \mu \mathrm{g} / \mathrm{kg}$, respectively (Table 1), which were equivalent to $17.1 \mu \mathrm{g} / \mathrm{kg}$ and $15.3-18.1 \mu \mathrm{g} / \mathrm{kg}$, fresh wt., respectively. The results (Fig. 1) revealed that there was a significant difference between the mean As concentrations in food samples between the exposed and control groups $(\mathrm{p}<0.001)$, while the mean As concentration in food samples collected from exposed group was 12.5 times higher than in the unexposed group. The highest concentrations of tAs were $1975 \mu \mathrm{g} / \mathrm{kg}$ (DW) and $395 \mu \mathrm{g} / \mathrm{kg}$ (FW) from sample RC1. The tAs concentration in the diets of children in Sonora, Mexico ranged from 50 to $1150 \mu \mathrm{g} / \mathrm{kg}$, dry wt (García-Rico et al., 2012), which was much lower than reported in this study.

It is important ot note here that although children from the control group live in municipal areas and use tap water $(\mathrm{As}<1 \mu \mathrm{g} / \mathrm{L})$ for drinking and cooking, we do not know whether they use food items that are low in As. Generally in the municipal and city areas of Bangladesh, food crops including rice, vegetables and pulses are sourced from Ascontaminated villages which are available in local markets. In this study, we were not sure about the sources of food crops for both the exposed and control groups, whether they originated from contaminated or uncontaminated areas or mixed agro-ecological zones. However, since As concentrations in composite food samples for the exposed group were much higher than those in the control group, we expect that As concentration in cooking water contributed to the increase in As in the cooked food composites. It is also expected that the cooking procedure would have affected the concentration of As in food samples (Bae et al., 2002; Laparra et al., 2005). 


\subsection{Inorganic As content and speciation}

n this study, inorganic As was the major species present in the food samples (Table 2) with an average of $74 \%$ (range 49-91\%). This is similar to the study conducted by Laparra et al. (2005) who reported $77 \%$ (range: 32-103\%) of iAs in cooked rice. Smith et al. (2006) reported iAs content of $87 \%$ and $96 \%$ in cooked rice and vegetables, respectively, in samples from Bangladesh. Ohno et al. (2007) found up to $100 \%$ of iAs in cooked rice from Bangladesh. Based on their duplicate diet survey conducted in Pabna, Bangladesh, Kile et al. (2007) reported that on average $82 \%$ of As present in food samples was iAs ( $n=35)$. We could not detect any MMA (V) in the food samples but DMA (V) was present in all samples except RC 8.

The iAs concentration in the diets of children in Sonora, Mexico was 23 to $88 \mu \mathrm{g} / \mathrm{kg}$, dry wt (García-Rico et al., 2012), which is much lower than the present study. The higher iAs (289 to $1624 \mu \mathrm{g} / \mathrm{kg}$, dry wt) detected in this study could be attributed to both cooking process and As-contaminated water used for cooking (Bae et al., 2002; Laparra et al., 2005; Zhuang et al., 2016). Laparra et al. (2005) reported a 5-17 fold increase in iAs content in the rice, after cooking with simulated As-contaminated water. This to a great extent reflects the reality of the situation concerning As-endemic areas throughout Asia. A recent study reported that cooking water $(84-105 \mu \mathrm{g} / \mathrm{l})$ significantly increased As concentration in sunned (24-337\%) and parboiled rice (114\%) (Chowdhury et al., 2020).

Maximum tolerance level of iAs in the rice (uncooked) for infants and young children is $100 \mu \mathrm{g} / \mathrm{kg}$ as recommended by the European Union (EU) (Ashmore et al., 2019). Out of 14 samples in the exposed group, all exceeded the EU safe level for infants and young children. Simulating the cooking practices followed in Asian As-endemic areas, Laparra et al. (2005) reported that both tAs and iAs increased when cooking with As-contaminated water and BAs 
depends on toxic iAs content. However, iAs in cooked rice could be more harmful due to the high bioaccessibility of As (>90\%) compared to raw rice (Laparra et al., 2005).

\subsection{BAs in cooked food composite}

The bioaccessible fractions of As (mean $\pm \mathrm{SD}$ ) determined in both in-vitro GP and GIP digestion were $91 \pm 13 \%$ (range $68-106 \%$ ) and $98 \pm 11 \%$ (range $72-117 \%$ ), respectively (Table 1). No significant difference were observed between the two phases (GP and GIP) although slightly more BAs is found in the GIP, which could be due to the effect of time. There was no noticeable difference of BAs between the samples collected from the control and exposed group. In Sonora, Mexico, BAs ranged from 4 to 97\% (mean 44\%) (García-Rico et al., 2012), hence, the average value of BAs was much higher in this study compared to Sonora. In our previous study, we determined in-vivo BAs in various rice genotypes ranging from $25-94 \%$ and we reported that the BAs varied based on rice varieties (Islam et al., 2017a). Cooking process affects the BAs both in GP and GIP extraction as Zhuang et al. (2016) reported that BAs in raw rice using GP and GIP extraction were 62-93\% and $75-96 \%$, respectively, whereas $38-67 \%$ and $72-80 \%$ were evident in cooked rice. Several studies have investigated the BAs, which ranged from $20 \%$ to $99 \%$ considering rice, seaweed, mushroom, radish and shrimp using different in-vitro methods (Table 2). Based on the limited data of BAs regarding cooked and composite food samples further analysis is recommended and particularly for children's diets from other As-contaminated areas.

The concentrations of tAs, iAs and BAs in both GP and GIP in food composite samples of the exposed group were significantly higher $(\mathrm{p}<0.001)$ than the control group (Figs. 1A and B). There was, however, no noticeable difference in BAs fraction (shown as percentage) between the control and exposed groups. No correlation was observed between 
tAs, iAs and BAs with cooking water. This could be attributed to the food composites, including types of rice, vegetables, fish and pulses used in this study.

Bioaccessibility is generally influenced by the level of contamination in food samples (Zhuang et al., 2016). The linear regression illustrated in Fig. 2 displays statistically significant relationships $\left(\mathrm{R}^{2}=0.964-0.983, \mathrm{p}<0.001\right)$ between tAs with iAs and BAs (both GP and GIP) in composite food samples, which confirmed that BAs does rely on As concentration (Zhuang et al., 2016). A similar strong relationship $\left(\mathrm{R}^{2}=0.928, \mathrm{p}<0.01\right)$ has been found between contamination level and bioaccessibility of As in raw rice, and this dose's proportional relationship was considered for the purposes of risk assessment (Zhuang et al., 2016).

\subsection{Potential health risk assessment}

Different risk assessment indices such as EDDI, HQ, CR have been calculated using the generated data of different cooked food composites for 31 children, which is presented in Table 3. Daily intake of tAs and iAs ranged from 0.84-7.75 (mean: $2.7 \pm 1.8$ and median: 2.1) $\mu \mathrm{g}$ per kg/ BW and 0.41-6.38 (mean: $2.0 \pm 1.5$ and median: 1.7$) \mu \mathrm{g}$ per kg/ BW, respectively. In this study, the exposed group had unusually higher values of As intake than the control group. Daily intake of tAs was $2.7(0.15-10.49) \mu \mathrm{g}$ per kg/BW in García-Rico et al. (2012) study, similar to our findings, yet daily intake of iAs $0.52(0.06-1.11) \mu \mathrm{g}$ per $\mathrm{kg} / \mathrm{BW}$ was much lower than this study. A few studies reported higher iAs intake than our findings (Díaz et al., 2004; Martí-Cid et al., 2007). The recommended upper limit for iAs exposure by the Joint FAO/WHO Expert Committee on Food Additives (JECFA) using the benchmark dose lower confidence limit for a $0.5 \%$ (BMDL0.5) increased incidence of lung cancer is $3 \mu \mathrm{g} / \mathrm{kg}$ BW per day (Cubadda et al., 2017). The mean iAs exposure in this study was below the upper recommended limit of $3 \mu \mathrm{g} / \mathrm{kg}$ BW per day although the maximum exposure is more than 
double the limit. Overall, $32 \%$ of the children in our study exceeded the above tolerance level, which is also consistent with the $32 \%$ reported by (Kile et al., 2007) based on a duplicate dietary survey at Pabna district in Bangladesh. The USEPA has stated that there is no "safe" level of exposure to iAs because it is very toxic. Inorganic As is directly related to BAs, so there is a need to elucidate the risk assessment. A recent study showed that regulation limits in most countries do not take into account of the environmental interfaces such as mobility of trace elements in plants. It concluded that there were reduced limits of trace elements and consequently health risk associated with As were underestimated (Antoniadis et al., 2019).

Considering BAs as the input parameter for As, EDDI value was $0.35-6.2 \mu \mathrm{g} / \mathrm{kg} \mathrm{BW}$ per day which was substantially higher than that of the control group in this study (Table 3) and higher than the US-based study of Shibata et al. (2016) who reported $0.82-1.1 \mu \mathrm{g} / \mathrm{kg}$ BW per day and the value of $0.53-0.74 \mu \mathrm{g} / \mathrm{kg}$ BW per day as reported by Zhuang et al. (2016). In this study, the HQ ranged from 1.2-20.5 (mean: 6.8 and median: 5.6) and the highest value was for Sh-B1 in the RC 1 group (Table 3, Fig. 3). All participants in the study area exceeded the tolerance level of HQ $(>1)$ that could induce adverse health effects, and HQ was less than 1 in the control group. Zhuang et al. (2016) found HQ value of 2.3-5.8 for cooked rice while (Shibata et al., 2016) stated values of 0.02-0.37 and 0.19-5.17 for acute and chronic doses of As from rice cereal and other dietary sources for infants and toddlers in the USA, respectively, which were all much lower than this study. Based on the CR assessment, all children in this study had a risk level greater than $10^{-4}$ and Sh-G1 in the group showed the highest risk of $9.2 \times 10^{-3}$. The CR value in this study was notably higher than what Fakhri et al. (2018) found $(0.2-5.5) \times 10^{-5}$ for shrimp but much lower than the value of $(4.5-5.5) \times 10^{-2}$ reported for rice in Iran. 
To the best of our knowledge this is the first study on bioaccessibility of As in children's composite diet over single food item comparing exposed and non-exposed participants in Bangladesh. It is important to note that all soluble fractions of metals are not bioavailable/absorbable in the human body (Laparra et al., 2005). Furthermore the in-vitro metal bioavailability technique has many problems and limitations, for example, human physiology of food digestion is quite complex, involves many biochemical reactions and varies from person to person. Also, the amount of soluble/digested metals is not fully accessible or absorbable to animal organs (Van Campen and Glahn, 1999). Therefore, further research is recommended and both in-vitro and in-vivo bioaccessibility models using a wide range of samples must be considered.

\section{Conclusion}

This study evaluated the tAs, iAs and BAs in food composites consumed by children in Bangladesh, comparing samples from As exposed and unexposed (based on As in drinking water) groups. Results indicated that exposure to iAs from food composite is one of the major risks to health due to very high bioaccessibility and consequently should be considered a high priority public health issue in Bangladesh where major mitigation measures are focused on drinking water. This study revealed that the mean As concentration in food composite samples from the exposed group was much higher than those of the unexposed group. It also appears that BAs was higher in GIP digestion than GP digestion in food composites. Based on the BAs results, the mean EDDI of As from food composite was just below the JECFA's recommended upper limit of $3 \mu \mathrm{g} / \mathrm{kg}$ BW per day. The higher values of HQ and CR observed for the exposed group indicated high risk to children in As-endemic areas. As a part of routine As monitoring in Bangladesh, further research is required with larger sample sizes along with other food components to estimate the actual risk of As from food intake. Furthermore, 
considerable attention must be given to lowering of As in food to curtail exposure and health risk in As-endemic populations, especially children. Certain practices such as use of As-safe cooking water for food preparation and appropriate cooking methods to reduce As content should be advocated in As-endemic areas to ensure consumption of food, especially rice in a protective way. This study highlights the importance of BAs estimation in food and provides a framework for better exposure and risk assessment.

\section{Acknowledgements}

We are grateful to the authority of the GCER, The University of Newcastle for laboratory support. Financial support from CRC CARE is highly appreciated. This study was also partially supported by a Fox Fellowship grant from Wagner College, New York, USA. Authors are grateful to Mr Sanjit Kumer Shaha, Diabetic Association of Bangladesh for his help in sampling the food samples.

\section{Declaration of interests}

Authors declare there are no conflicts of interest.

\section{Authors contributions}

MMR, concept, design of the study, analysed the data and wrote the first draft of the manuscript, final approval of the manuscript; ABS and MRI, data analysis and interpretation and drafted the manuscript; MA, STA and GA, participated in data collection, analysis and edited the manuscript; DM and RN revised and edited the manuscript critically, provided technical oversight to the manuscript. All authors read and commented on drafts of the manuscript. 


\section{References}

Abtahi M, Fakhri Y, Oliveri Conti G, Keramati H, Zandsalimi Y, Bahmani Z, et al. Heavy metals ( $\mathrm{As}, \mathrm{Cr}, \mathrm{Pb}, \mathrm{Cd}$ and $\mathrm{Ni}$ ) concentrations in rice (Oryza sativa) from Iran and associated risk assessment: a systematic review. Toxin reviews 2017; 36: 331-341.

Abtahi M, Fakhri Y, Oliveri Conti G, Keramati H, Zandsalimi Y, Bahmani Z, et al. Heavy metals ( $\mathrm{As}, \mathrm{Cr}, \mathrm{Pb}, \mathrm{Cd}$ and $\mathrm{Ni}$ ) concentrations in rice (Oryza sativa) from Iran and associated risk assessment: a systematic review. Toxin reviews 2017; 36: 331-341.

Antoniadis V, Levizou E, Shaheen SM, Ok YS, Sebastian A, Baum C, et al. Trace elements in the soil-plant interface: Phytoavailability, translocation, and phytoremediation-A review. Earth-Science Reviews 2017; 171: 621-645.

Antoniadis V, Shaheen SM, Levizou E, Shahid M, Niazi NK, Vithanage M, et al. A critical prospective analysis of the potential toxicity of trace element regulation limits in soils worldwide: Are they protective concerning health risk assessment?-A review. Environment international 2019; 127: 819-847.

Ashmore E, Molyneux S, Watson S, Miles G, Pearson A. Inorganic arsenic in rice and rice products in New Zealand and Australia. Food Additives \& Contaminants: Part B 2019; $12: 275-279$.

Bae M, Watanabe C, Inaoka T, Sekiyama M, Sudo N, Bokul MH, et al. Arsenic in cooked rice in Bangladesh. The Lancet 2002; 360: 1839-1840.

Carbonell-Barrachina ÁA, Wu X, Ramírez-Gandolfo A, Norton GJ, Burló F, Deacon C, et al. Inorganic arsenic contents in rice-based infant foods from Spain, UK, China and USA. Environmental Pollution 2012; 163: 77-83. 
Chakraborti D, Rahman MM, Das B, Murrill M, Dey S, Mukherjee SC, et al. Status of groundwater arsenic contamination in Bangladesh: a 14-year study report. Water Research 2010; 44: 5789-5802.

Chi H, Zhang Y, Williams PN, Lin S, Hou Y, Cai C. In Vitro Model To Assess Arsenic Bioaccessibility and Speciation in Cooked Shrimp. Journal of agricultural and food chemistry 2018; 66: 4710-4715.

Chowdhury NR, Das A, Joardar M, De A, Mridha D, Das R, et al. Flow of arsenic between rice grain and water: Its interaction, accumulation and distribution in different fractions of cooked rice. Science of The Total Environment 2020: 138937.

Cubadda F, Jackson BP, Cottingham KL, Van Horne YO, Kurzius-Spencer M. Human exposure to dietary inorganic arsenic and other arsenic species: State of knowledge, gaps and uncertainties. Science of the total environment 2017; 579: 1228-1239.

Díaz OP, Leyton I, Muñoz O, Núñez N, Devesa V, Súñer MA, et al. Contribution of water, bread, and vegetables (raw and cooked) to dietary intake of inorganic arsenic in a rural village of Northern Chile. Journal of Agricultural and Food Chemistry 2004; 52: 1773-1779.

Fakhri Y, Bjørklund G, Bandpei AM, Chirumbolo S, Keramati H, Pouya RH, et al. Concentrations of arsenic and lead in rice (Oryza sativa L.) in Iran: a systematic review and carcinogenic risk assessment. Food and chemical toxicology 2018; 113: 267-277. 
García-Rico L, Tejeda-Valenzuela L, Vélez D, Montoro R. Content of selenium, total and inorganic arsenic and bioaccessibility of arsenic in children diets of Mexico. Journal of the Science of Food and Agriculture 2012; 92: 1725-1731.

He Y, Pedigo CE, Lam B, Cheng Z, Zheng Y. Bioaccessibility of arsenic in various types of rice in an in vitro gastrointestinal fluid system. Journal of Environmental Science and Health, Part B 2012; 47: 74-80.

Hu L, Zhang B, Wu D, Fan H, Tu J, Liu W, et al. Estimation of arsenic bioaccessibility in raw and cooked radish using simulated in vitro digestion. Food \& function 2019; 10: 14261432.

Islam S, Rahman MM, Duan L, Islam M, Kuchel T, Naidu R. Variation in arsenic bioavailability in rice genotypes using swine model: An animal study. Science of the Total Environment 2017a; 599: 324-331.

Islam S, Rahman MM, Islam M, Naidu R. Geographical variation and age-related dietary exposure to arsenic in rice from Bangladesh. Science of the Total Environment 2017b; 601: 122-131.

Islam S, Rahman MM, Rahman MA, Naidu R. Inorganic arsenic in rice and rice-based diets: health risk assessment. Food Control 2017c; 82: 196-202.

Kafaoglu B, Fisher A, Hill S, Kara D. Determination and evaluation of element bioaccessibility in some nuts and seeds by in-vitro gastro-intestinal method. Journal of Food Composition and Analysis 2016; 45: 58-65. 
Kile ML, Houseman EA, Breton CV, Smith T, Quamruzzaman Q, Rahman M, et al. Dietary arsenic exposure in Bangladesh. Environmental health perspectives 2007; 115: 889893.

Koch I, Dee J, House K, Sui J, Zhang J, McKnight-Whitford A, et al. Bioaccessibility and speciation of arsenic in country foods from contaminated sites in Canada. Science of the Total Environment 2013; 449: 1-8.

Laparra JM, Vélez D, Barberá R, Farré R, Montoro R. Bioavailability of inorganic arsenic in cooked rice: practical aspects for human health risk assessments. Journal of agricultural and food chemistry 2005; 53: 8829-8833.

Llorente-Mirandes T, Llorens-Munoz M, Funes-Collado V, Sahuquillo A, López-Sánchez JF. Assessment of arsenic bioaccessibility in raw and cooked edible mushrooms by a PBET method. Food chemistry 2016; 194: 849-856.

Martí-Cid R, Bocio A, Llobet JM, Domingo JL. Intake of chemical contaminants through fish and seafood consumption by children of Catalonia, Spain: health risks. Food and Chemical Toxicology 2007; 45: 1968-1974.

Mwale T, Rahman MM, Mondal D. Risk and benefit of different cooking methods on essential elements and arsenic in rice. International journal of environmental research and public health 2018; 15: 1056.

Ohno K, Yanase T, Matsuo Y, Kimura T, Rahman MH, Magara Y, et al. Arsenic intake via water and food by a population living in an arsenic-affected area of Bangladesh. Science of the Total Environment 2007; 381: 68-76. 
Rahman MM, Asaduzzaman M, Naidu R. Arsenic exposure from rice and water sources in the Noakhali District of Bangladesh. Water Quality, Exposure and Health 2011; 3: 110.

Rahman MM, Asaduzzaman M, Naidu R. Consumption of arsenic and other elements from vegetables and drinking water from an arsenic-contaminated area of Bangladesh. Journal of hazardous materials 2013; 262: 1056-1063.

Rahman MM, Chowdhury UK, Mukherjee SC, Mondal BK, Paul K, Lodh D, et al. Chronic arsenic toxicity in Bangladesh and West Bengal, India-a review and commentary. Journal of Toxicology: Clinical Toxicology 2001; 39: 683-700.

Rahman MM, Owens G, Naidu R. Arsenic levels in rice grain and assessment of daily dietary intake of arsenic from rice in arsenic-contaminated regions of Bangladeshimplications to groundwater irrigation. Environmental Geochemistry and Health 2009; 31: 179-187.

Sengupta M, Hossain M, Mukherjee A, Ahamed S, Das B, Nayak B, et al. Arsenic burden of cooked rice: traditional and modern methods. Food and Chemical Toxicology 2006; 44: $1823-1829$.

Shew AM, Durand-Morat A, Putman B, Nalley LL, Ghosh A. Rice intensification in Bangladesh improves economic and environmental welfare. Environmental Science \& Policy 2019; 95: 46-57.

Shibata T, Meng C, Umoren J, West H. Risk assessment of arsenic in rice cereal and other dietary sources for infants and toddlers in the US. International journal of environmental research and public health 2016; 13: 361 . 
Signes-Pastor AJ, Carey M, Meharg AA. Inorganic arsenic in rice-based products for infants and young children. Food chemistry 2016; 191: 128-134.

Signes-Pastor AJ, Al-Rmalli SW, Jenkins RO, Carbonell-Barrachina ÁA, Haris PI. Arsenic bioaccessibility in cooked rice as affected by arsenic in cooking water. Journal of food science 2012; 77: T201-T206.

Smith NM, Lee R, Heitkemper DT, Cafferky KD, Haque A, Henderson AK. Inorganic arsenic in cooked rice and vegetables from Bangladeshi households. Science of the Total Environment 2006; 370: 294-301.

Trenary HR, Creed PA, Young AR, Mantha M, Schwegel CA, Xue J, et al. An in vitro assessment of bioaccessibility of arsenicals in rice and the use of this estimate within a probabilistic exposure model. Journal of exposure science \& environmental epidemiology 2012; 22: 369-375.

Van Campen DR, Glahn RP. Micronutrient bioavailability techniques: accuracy, problems and limitations. Field Crops Research 1999; 60: 93-113.

von Ehrenstein OS, Poddar S, Yuan Y, Mazumder DG, Eskenazi B, Basu A, et al. Children's intellectual function in relation to arsenic exposure. Epidemiology 2007: 44-51.

Wasserman GA, Liu X, Parvez F, Ahsan H, Factor-Litvak P, van Geen A, et al. Water arsenic exposure and children's intellectual function in Araihazar, Bangladesh. Environmental health perspectives 2004: 1329-1333.

Zhuang P, Zhang C, Li Y, Zou B, Mo H, Wu K, et al. Assessment of influences of cooking on cadmium and arsenic bioaccessibility in rice, using an in vitro physiologically-based extraction test. Food chemistry 2016; 213: 206-214. 
Antoniadis V, Levizou E, Shaheen SM, Ok YS, Sebastian A, Baum C, et al. Trace elements in the soil-plant interface: Phytoavailability, translocation, and phytoremediation-A review. Earth-Science Reviews 2017; 171: 621-645.

Antoniadis V, Shaheen SM, Levizou E, Shahid M, Niazi NK, Vithanage M, et al. A critical prospective analysis of the potential toxicity of trace element regulation limits in soils worldwide: Are they protective concerning health risk assessment?-A review. Environment international 2019; 127: 819-847.

Ashmore E, Molyneux S, Watson S, Miles G, Pearson A. Inorganic arsenic in rice and rice products in New Zealand and Australia. Food Additives \& Contaminants: Part B $2019 ; 12: 275-279$.

Bae M, Watanabe C, Inaoka T, Sekiyama M, Sudo N, Bokul MH, et al. Arsenic in cooked rice in Bangladesh. The Lancet 2002; 360: 1839-1840.

Carbonell-Barrachina ÁA, Wu X, Ramírez-Gandolfo A, Norton GJ, Burló F, Deacon C, et al. Inorganic arsenic contents in rice-based infant foods from Spain, UK, China and USA. Environmental Pollution 2012; 163: 77-83.

Chakraborti D, Rahman MM, Das B, Murrill M, Dey S, Mukherjee SC, et al. Status of groundwater arsenic contamination in Bangladesh: a 14-year study report. Water Research 2010; 44: 5789-5802.

Chi H, Zhang Y, Williams PN, Lin S, Hou Y, Cai C. In Vitro Model To Assess Arsenic Bioaccessibility and Speciation in Cooked Shrimp. Journal of agricultural and food chemistry 2018; 66: 4710-4715. 
Chowdhury NR, Das A, Joardar M, De A, Mridha D, Das R, et al. Flow of arsenic between rice grain and water: Its interaction, accumulation and distribution in different fractions of cooked rice. Science of The Total Environment 2020: 138937.

Cubadda F, Jackson BP, Cottingham KL, Van Horne YO, Kurzius-Spencer M. Human exposure to dietary inorganic arsenic and other arsenic species: State of knowledge, gaps and uncertainties. Science of the total environment 2017; 579: 1228-1239.

Díaz OP, Leyton I, Muñoz O, Núñez N, Devesa V, Súñer MA, et al. Contribution of water, bread, and vegetables (raw and cooked) to dietary intake of inorganic arsenic in a rural village of Northern Chile. Journal of Agricultural and Food Chemistry 2004; 52: 1773-1779.

Fakhri Y, Bjørklund G, Bandpei AM, Chirumbolo S, Keramati H, Pouya RH, et al. Concentrations of arsenic and lead in rice (Oryza sativa L.) in Iran: a systematic review and carcinogenic risk assessment. Food and chemical toxicology 2018; 113: 267-277.

García-Rico L, Tejeda-Valenzuela L, Vélez D, Montoro R. Content of selenium, total and inorganic arsenic and bioaccessibility of arsenic in children diets of Mexico. Journal of the Science of Food and Agriculture 2012; 92: 1725-1731.

He Y, Pedigo CE, Lam B, Cheng Z, Zheng Y. Bioaccessibility of arsenic in various types of rice in an in vitro gastrointestinal fluid system. Journal of Environmental Science and Health, Part B 2012; 47: 74-80. 
Hu L, Zhang B, Wu D, Fan H, Tu J, Liu W, et al. Estimation of arsenic bioaccessibility in raw and cooked radish using simulated in vitro digestion. Food \& function 2019; 10: 14261432.

IRIS, 2013. Integrated risk information systems. US Environmental Protection Agency.

Islam S, Rahman MM, Duan L, Islam M, Kuchel T, Naidu R. Variation in arsenic bioavailability in rice genotypes using swine model: An animal study. Science of the Total Environment 2017a; 599: 324-331.

Islam S, Rahman MM, Islam M, Naidu R. Geographical variation and age-related dietary exposure to arsenic in rice from Bangladesh. Science of the Total Environment 2017b; 601: 122-131.

Islam S, Rahman MM, Rahman MA, Naidu R. Inorganic arsenic in rice and rice-based diets: health risk assessment. Food Control 2017c; 82: 196-202.

Kafaoglu B, Fisher A, Hill S, Kara D. Determination and evaluation of element bioaccessibility in some nuts and seeds by in-vitro gastro-intestinal method. Journal of Food Composition and Analysis 2016; 45: 58-65.

Kile ML, Houseman EA, Breton CV, Smith T, Quamruzzaman Q, Rahman M, et al. Dietary arsenic exposure in Bangladesh. Environmental health perspectives 2007; 115: 889893.

Koch I, Dee J, House K, Sui J, Zhang J, McKnight-Whitford A, et al. Bioaccessibility and speciation of arsenic in country foods from contaminated sites in Canada. Science of the Total Environment 2013; 449: 1-8 
Laparra JM, Vélez D, Barberá R, Farré R, Montoro R. Bioavailability of inorganic arsenic in cooked rice: practical aspects for human health risk assessments. Journal of agricultural and food chemistry 2005; 53: 8829-8833.

Lee K-W, Lee SG. Inorganic Arsenic Bioaccessibility/Bioavailability from Cooked Rice Using In Vitro Digestion/Caco-2 Cell Model. The FASEB Journal 2017; 31: 608.6608.6 .

Llorente-Mirandes T, Llorens-Munoz M, Funes-Collado V, Sahuquillo A, López-Sánchez JF. Assessment of arsenic bioaccessibility in raw and cooked edible mushrooms by a PBET method. Food chemistry 2016; 194: 849-856.

Martí-Cid R, Bocio A, Llobet JM, Domingo JL. Intake of chemical contaminants through fish and seafood consumption by children of Catalonia, Spain: health risks. Food and Chemical Toxicology 2007; 45: 1968-1974.

Mwale T, Rahman MM, Mondal D. Risk and benefit of different cooking methods on essential elements and arsenic in rice. International journal of environmental research and public health 2018; 15: 1056.

Ohno K, Yanase T, Matsuo Y, Kimura T, Rahman MH, Magara Y, et al. Arsenic intake via water and food by a population living in an arsenic-affected area of Bangladesh. Science of the Total Environment 2007; 381: 68-76.

Rahman MM, Asaduzzaman M, Naidu R. Arsenic exposure from rice and water sources in the Noakhali District of Bangladesh. Water Quality, Exposure and Health 2011; 3: 110. 
Rahman MM, Asaduzzaman M, Naidu R. Consumption of arsenic and other elements from vegetables and drinking water from an arsenic-contaminated area of Bangladesh. Journal of hazardous materials 2013; 262: 1056-1063.

Rahman MM, Chowdhury UK, Mukherjee SC, Mondal BK, Paul K, Lodh D, et al. Chronic arsenic toxicity in Bangladesh and West Bengal, India—a review and commentary. Journal of Toxicology: Clinical Toxicology 2001; 39: 683-700.

Rahman MM, Owens G, Naidu R. Arsenic levels in rice grain and assessment of daily dietary intake of arsenic from rice in arsenic-contaminated regions of Bangladeshimplications to groundwater irrigation. Environmental Geochemistry and Health 2009; 31: 179-187.

Sengupta M, Hossain M, Mukherjee A, Ahamed S, Das B, Nayak B, et al. Arsenic burden of cooked rice: traditional and modern methods. Food and Chemical Toxicology 2006; 44: $1823-1829$

Shew AM, Durand-Morat A, Putman B, Nalley LL, Ghosh A. Rice intensification in Bangladesh improves economic and environmental welfare. Environmental Science \& Policy 2019; 95: 46-57.

Shibata T, Meng C, Umoren J, West H. Risk assessment of arsenic in rice cereal and other dietary sources for infants and toddlers in the US. International journal of environmental research and public health 2016; 13: 361

Signes-Pastor AJ, Carey M, Meharg AA. Inorganic arsenic in rice-based products for infants and young children. Food Chemistry 2016; 191: 128-134. 
Signes-Pastor AJ, Al-Rmalli SW, Jenkins RO, Carbonell-Barrachina ÁA, Haris PI. Arsenic bioaccessibility in cooked rice as affected by arsenic in cooking water. Journal of food science 2012; 77: T201-T206.

Smith NM, Lee R, Heitkemper DT, Cafferky KD, Haque A, Henderson AK. Inorganic arsenic in cooked rice and vegetables from Bangladeshi households. Science of the Total Environment 2006; 370: 294-301.

Sun G-X, Van de Wiele T, Alava P, Tack F, Du Laing G. Arsenic in cooked rice: effect of chemical, enzymatic and microbial processes on bioaccessibility and speciation in the human gastrointestinal tract. Environmental Pollution 2012; 162: 241-246.

Trenary HR, Creed PA, Young AR, Mantha M, Schwegel CA, Xue J, et al. An in vitro assessment of bioaccessibility of arsenicals in rice and the use of this estimate within a probabilistic exposure model. Journal of exposure science \& environmental epidemiology 2012; 22: 369-375.

Van Campen DR, Glahn RP. Micronutrient bioavailability techniques: accuracy, problems and limitations. Field Crops Research 1999; 60: 93-113.

von Ehrenstein OS, Poddar S, Yuan Y, Mazumder DG, Eskenazi B, Basu A, et al. Children's intellectual function in relation to arsenic exposure. Epidemiology 2007: 44-51.

Wasserman GA, Liu X, Parvez F, Ahsan H, Factor-Litvak P, van Geen A, et al. Water arsenic exposure and children's intellectual function in Araihazar, Bangladesh. Environmental health perspectives 2004: 1329-1333. 
Zhuang P, Zhang C, Li Y, Zou B, Mo H, Wu K, et al. Assessment of influences of cooking on cadmium and arsenic bioaccessibility in rice, using an in vitro physiologically-based extraction test. Food chemistry 2016; 213: 206-214. 


\section{Declaration of interests}

Bioaccessibility, speciation and health risk assessment of arsenic in children diets from an endemic area of Bangladesh

$\bigotimes$ The authors declare that they have no known competing financial interests or personal relationships that could have appeared to influence the work reported in this paper.

$\square$ The authors declare the following financial interests/personal relationships, which may be considered as potential competing interests: 


\section{Highlights}

- Arsenic bioaccessibility and speciation in food composites of children diet.

- Inorganic arsenic in food composites was on an average $74 \%$.

- Arsenic in food composites influenced by contaminated cooking water.

- Arsenic bioaccessibility was higher in gastrointestinal (99\%) than gastric phase (92\%).

- HQ and CR from food intake indicated high risk to children. 

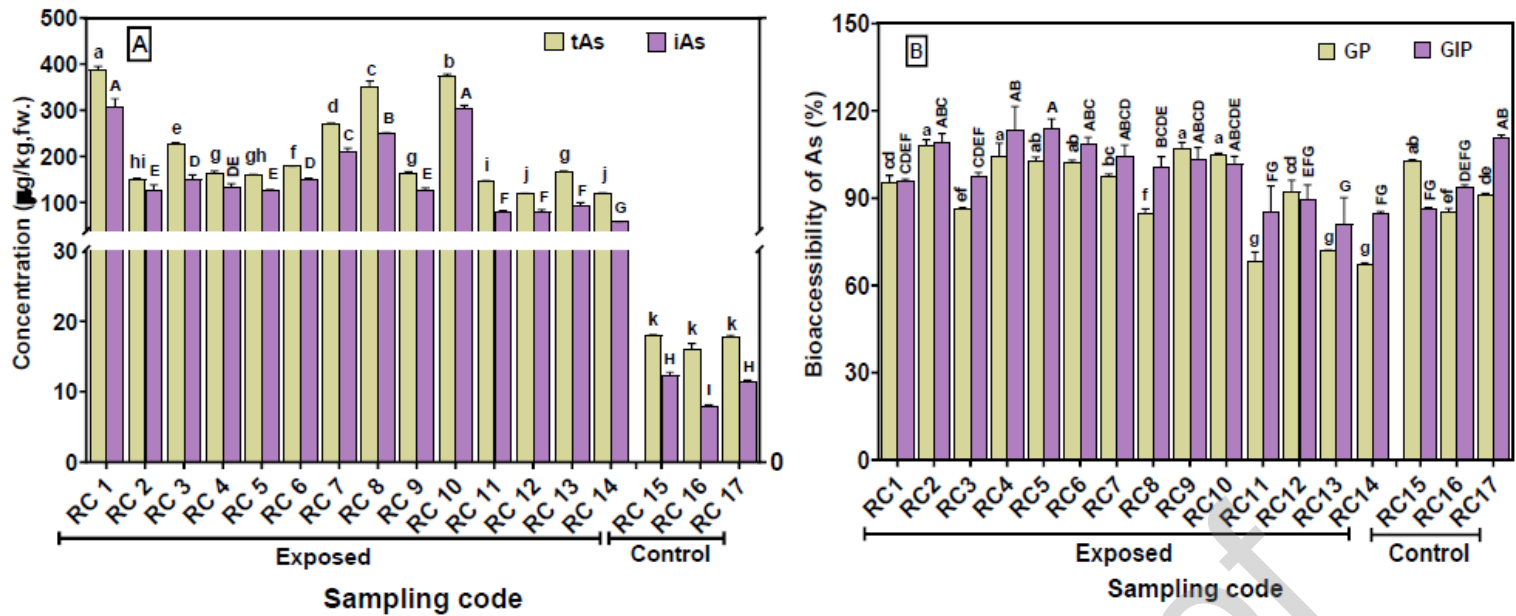

Fig. 1. Concentrations ( $\mu \mathrm{g} / \mathrm{kg}$ ) of (A) tAs, iAs and (B) BAs (GP and GIP) in food composites of children diets. Levels not connected by same letter are significantly different $(\mathrm{P}<0.001$, Student $\mathrm{t}$ test).

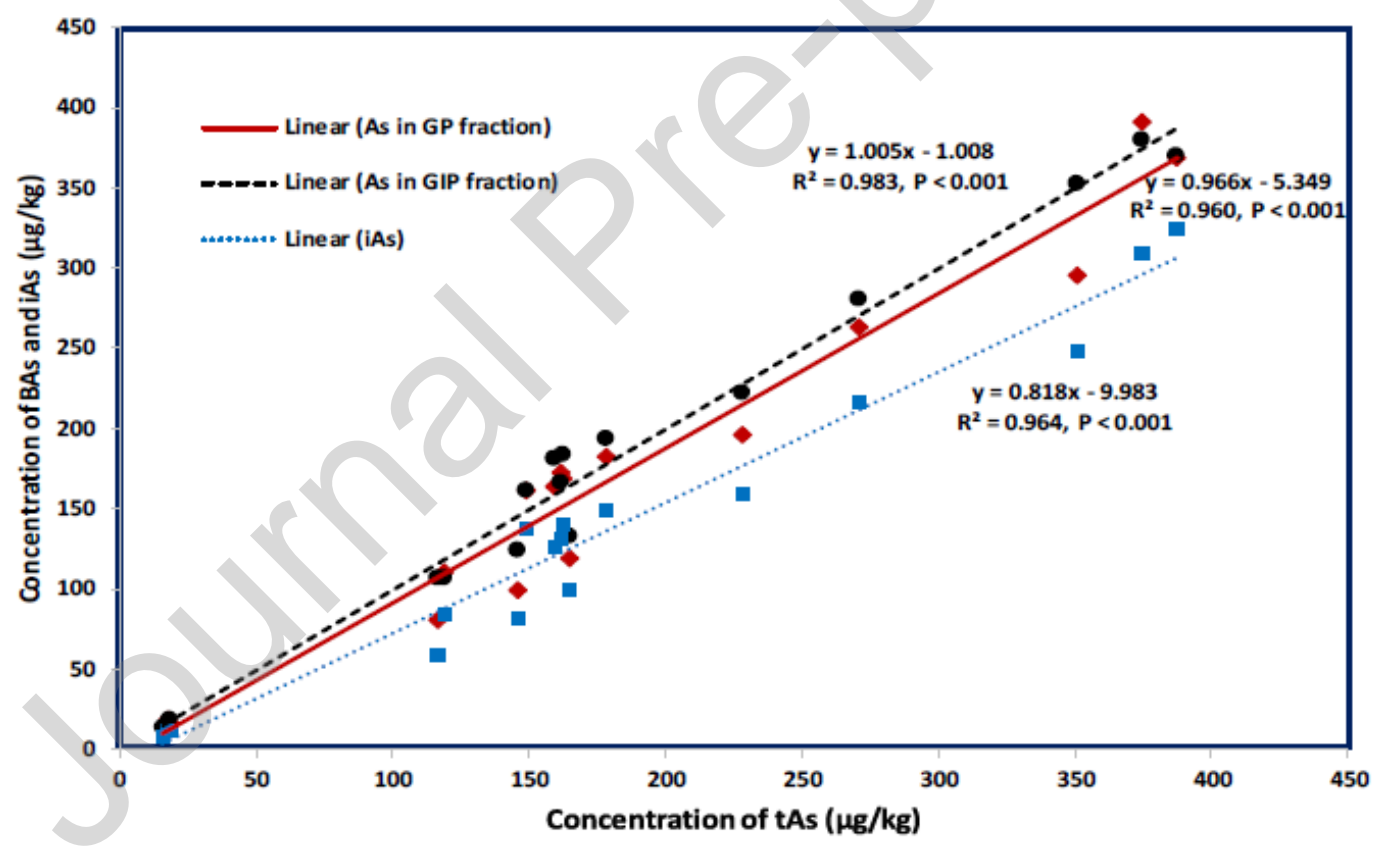

Fig. 2. Statistical correlation between iAs and BAs (GP and GIP) as a function tAs present in the children diets from Bangladesh. 

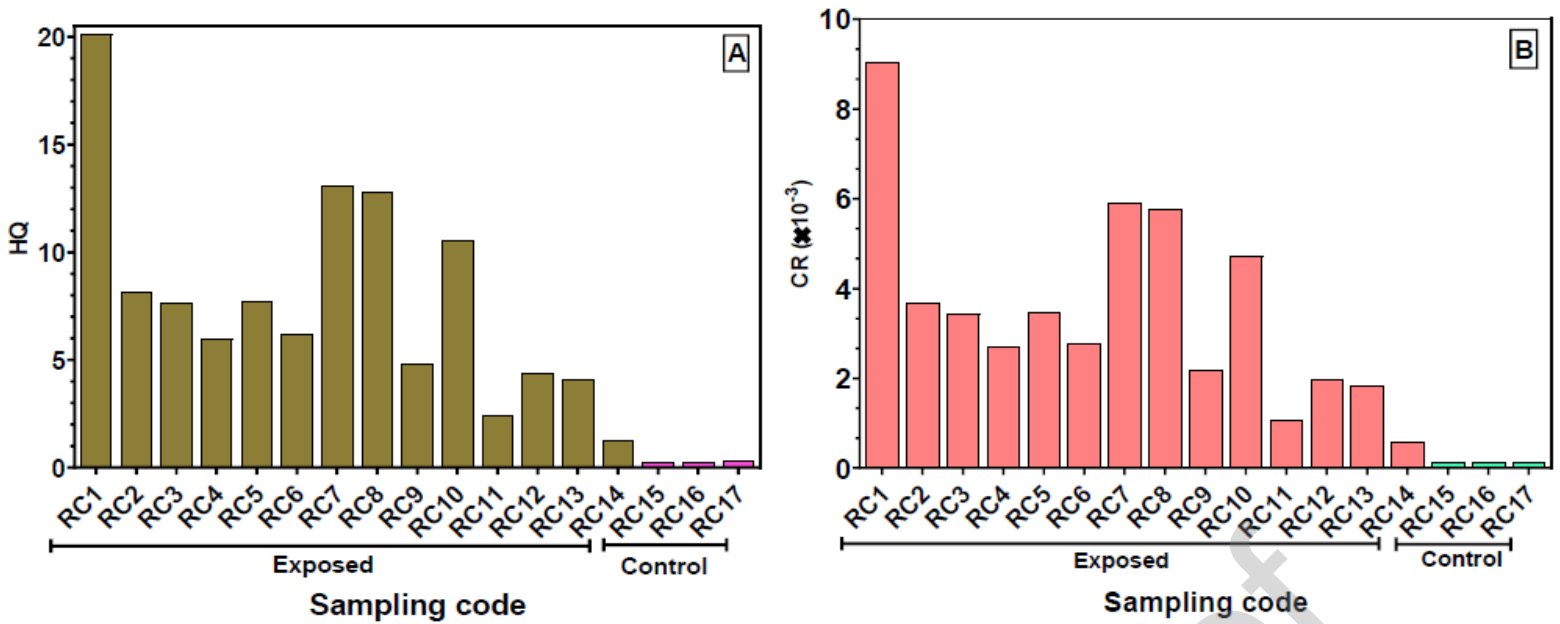

Fig. 3. Risk assessment of participant's children regarding (A) hazard quotient (HQ) and (B) cancer risk (CR) assessment.

Table 1. Concentrations of tAs, speciated As and BAs in food composites collected from

Bangladesh

SM Concentration (dry wt. basis), Concentration (fresh wt. basis), $(\mu \mathrm{g} / \mathrm{kg}$ )

PL $\quad(\mu \mathrm{g} / \mathrm{kg})$

ID

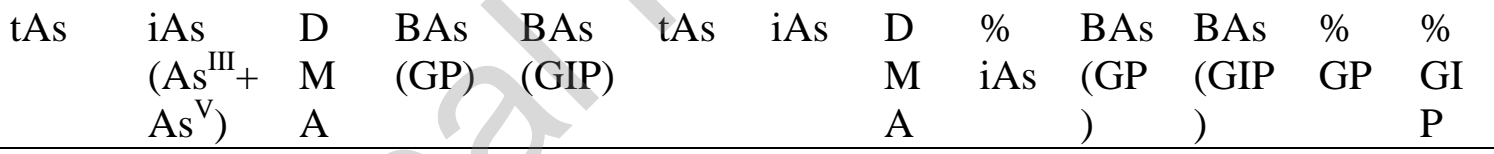

Exposed group

\begin{tabular}{llllllllllllllll}
$\mathrm{RC}$ & 1975 & 1624 & 25. & 1843 & 1908 & 325 & 325 & 5.1 & 82. & 368 & 381 & 93. & 96. \\
1 & & & 5 & & & & & & 2 & & & 3 & 6 \\
$\mathrm{RC}$ & 758 & 689 & 9.9 & 805 & 800 & 138 & 138 & 2.0 & 90. & 161 & 160 & 106 & 105 \\
2 & & & & & & & & & 9 & & & .1 & .5 \\
& & & & & & & & & & & & & & & \\
$\mathrm{RC}$ & 1147 & 798 & 13. & 994 & 1102 & 159 & 159 & 2.7 & 69. & 198 & 220 & 86. & 96. \\
3 & & & 6 & & & & & & 5 & & & 7 & 1 \\
$\mathrm{RC}$ & 839 & 702 & 12. & 840 & 887 & 141 & 140 & 2.5 & 83. & 168 & 177 & 100 & 105 \\
4 & & & 6 & & & & & & 7 & & & .1 & .7 \\
$\mathrm{RC}$ & 792 & 638 & 8.5 & 825 & 929 & 128 & 127 & 1.7 & 80. & 165 & 186 & 104 & 117 \\
5 & & & & & & & & & 5 & & & .1 & .2 \\
$\mathrm{RC}$ & 889 & 743 & 16. & 915 & 986 & 149 & 148 & 3.2 & 83. & 183 & 197 & 103 & 110 \\
6 & & & 2 & & & & & & 6 & & & .0 & .9 \\
$\mathrm{RC}$ & 1361 & 1085 & 15. & 1314 & 1360 & 217 & 217 & 3.2 & 79. & 263 & 272 & 96. & 99. \\
\hline
\end{tabular}




\begin{tabular}{|c|c|c|c|c|c|c|c|c|c|c|c|c|c|}
\hline 7 & & & 9 & & & & & & 7 & & & 5 & 9 \\
\hline $\begin{array}{l}\mathrm{RC} \\
8\end{array}$ & 1814 & 1245 & $\begin{array}{l}\mathrm{N} \\
\mathrm{D}\end{array}$ & 1504 & 1890 & 249 & 249 & $\begin{array}{l}\mathrm{N} \\
\mathrm{D}\end{array}$ & $\begin{array}{l}68 . \\
6\end{array}$ & 301 & 378 & $\begin{array}{l}82 . \\
9\end{array}$ & $\begin{array}{l}104 \\
.2\end{array}$ \\
\hline $\begin{array}{l}\mathrm{RC} \\
9\end{array}$ & 830 & 656 & $\begin{array}{l}11 . \\
4\end{array}$ & 868 & 820 & 131 & 131 & 2.3 & $\begin{array}{l}79 . \\
1\end{array}$ & 174 & 164 & $\begin{array}{l}104 \\
.7\end{array}$ & $\begin{array}{l}98 . \\
8\end{array}$ \\
\hline $\begin{array}{l}\mathrm{RC} \\
10\end{array}$ & 1852 & 1550 & $\begin{array}{l}31 . \\
7\end{array}$ & 1952 & 1933 & 310 & 310 & 6.3 & $\begin{array}{l}83 . \\
7\end{array}$ & 390 & 387 & $\begin{array}{l}105 \\
.4\end{array}$ & $\begin{array}{l}104 \\
.4\end{array}$ \\
\hline $\begin{array}{l}\mathrm{RC} \\
11\end{array}$ & 734 & 408 & $\begin{array}{l}26 . \\
9\end{array}$ & 525 & 691 & 81 & 81 & 5.4 & $\begin{array}{l}55 . \\
6\end{array}$ & 105 & 138 & $\begin{array}{l}71 . \\
4\end{array}$ & $\begin{array}{l}94 . \\
2\end{array}$ \\
\hline $\begin{array}{l}\mathrm{RC} \\
12\end{array}$ & 598 & 420 & 8.2 & 529 & 566 & 84 & 84 & 1.6 & $\begin{array}{l}70 . \\
4\end{array}$ & 106 & 113 & $\begin{array}{l}88 . \\
5\end{array}$ & $\begin{array}{l}94 . \\
6\end{array}$ \\
\hline $\begin{array}{l}\mathrm{RC} \\
13\end{array}$ & 839 & 495 & 5.6 & 605 & 602 & 99 & 99 & & 59. & 121 & 120 & $\begin{array}{l}72 . \\
1\end{array}$ & $\begin{array}{l}71 . \\
7\end{array}$ \\
\hline $\begin{array}{l}\mathrm{RC} \\
14\end{array}$ & 586 & 289 & 5.3 & 398 & 501 & 58 & 58 & & 49. & 79 & 100 & $\begin{array}{l}67 . \\
8\end{array}$ & $\begin{array}{l}85 \\
4\end{array}$ \\
\hline $\begin{array}{l}\text { Me } \\
\text { an }\end{array}$ & $\begin{array}{l}1073 \\
\pm 481\end{array}$ & $\begin{array}{l}811 \pm 4 \\
15\end{array}$ & $\begin{array}{l}15 \\
\pm 8\end{array}$ & $\begin{array}{l}995 \pm \\
484\end{array}$ & $\begin{array}{r}1070 \\
\pm 507\end{array}$ & $\begin{array}{l}162 \\
\pm 83\end{array}$ & $\begin{array}{l}162 \\
\pm 83\end{array}$ & $\begin{array}{l}3 \pm \\
1.8\end{array}$ & $\begin{array}{l}74 \\
\pm 1 \\
2\end{array}$ & $\begin{array}{l}199 \\
\pm 97\end{array}$ & $\begin{array}{l}214 \pm \\
101\end{array}$ & $\begin{array}{l}92 \\
\pm 1 \\
3\end{array}$ & $\begin{array}{l}99 \\
\pm 1 \\
1\end{array}$ \\
\hline $\begin{array}{l}\text { Ra } \\
\text { nge }\end{array}$ & $\begin{array}{l}587- \\
1976\end{array}$ & $\begin{array}{l}289- \\
1625\end{array}$ & $\begin{array}{l}\mathrm{N} \\
\mathrm{D}- \\
32\end{array}$ & $\begin{array}{l}398- \\
1952\end{array}$ & $\begin{array}{l}501- \\
1934\end{array}$ & $\begin{array}{l}58- \\
325\end{array}$ & $\begin{array}{l}58- \\
325\end{array}$ & $\begin{array}{l}\mathrm{N} \\
\mathrm{D}- \\
6\end{array}$ & $\begin{array}{l}49- \\
91\end{array}$ & $\begin{array}{l}80- \\
390\end{array}$ & $\begin{array}{l}100- \\
387\end{array}$ & $\begin{array}{l}68- \\
106\end{array}$ & $\begin{array}{l}72- \\
117\end{array}$ \\
\hline
\end{tabular}

Unexposed (control) group

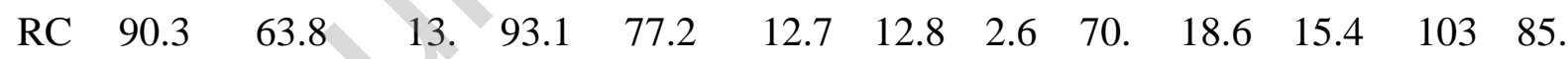

$\begin{array}{llllll}15 & 2 & 6 & .1 & 4\end{array}$

$\begin{array}{llllllllllllll}\mathrm{RC} & 76.3 & 38.9 & 10 . & 64.2 & 72.2 & 7.8 & 7.8 & 2.0 & 51 . & 12.8 & 14.4 & 84 . & 94 . \\ 16 & & & 2 & & & & & & 0 & & & 1 & 6\end{array}$

$\begin{array}{llllllllllllll}\mathrm{RC} & 90.0 & 58.2 & 14 . & 81.7 & 100.6 & 11.6 & 11.6 & 2.9 & 64 . & 16.3 & 20.1 & 90 . & 111\end{array}$

$\begin{array}{lllllll}17 & 5 & 6 & 8 & .7\end{array}$

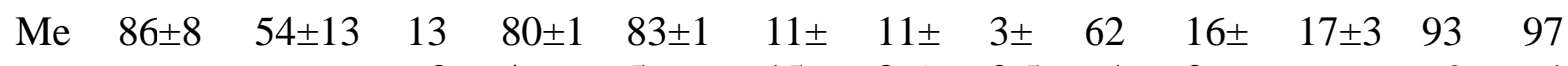

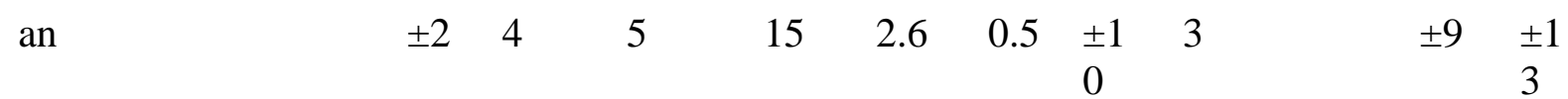

Ra 76-90 39-64 10- 64- 72- $\quad 8-\quad 8-\quad 2-3 \quad 51-\quad 13-\quad 14-\quad 84-\quad 85-$

\begin{tabular}{lllllllllll} 
nge & 15 & 93 & 101 & 13 & 13 & 71 & 19 & 20 & 103 & 112 \\
\hline
\end{tabular}

*fresh weight (FW)-after considering $80 \%$ moisture content in food composites 


\begin{tabular}{|c|c|c|c|}
\hline Food type & $\begin{array}{l}\mathrm{BA}(\%) \text { in } \\
\text { GP fraction }\end{array}$ & $\begin{array}{l}\text { BA }(\%) \text { in } \\
\text { GIP fraction }\end{array}$ & Reference \\
\hline $\begin{array}{l}\text { Food composites (cooked rice, } \\
\text { curry and dal) }\end{array}$ & $68-106$ & $72-117$ & This study \\
\hline Cooked rice & $78-81$ & - & (Alava et al., 2013) \\
\hline Raw shrimp & $76.9 \pm 4.3$ & - & (Chi et al., 2018) \\
\hline Boiled shrimp & $83.7 \pm 1.9$ & - & (Chi et al., 2018) \\
\hline Fried shrimp & $85.9 \pm 6.6$ & - & (Chi et al., 2018) \\
\hline Children diet & $4-97$ & - & (García-Rico et al., 2012) \\
\hline Cooked rice & $53-102$ & - & (He et al., 2012) \\
\hline Raw radish & $60.1 \pm 2.3$ & $97.5 \pm 1.2$ & (Hu et al., 2019) \\
\hline Boiled radish & $32.4 \pm 0.9$ & $52.1 \pm 1.1$ & (Hu et al., 2019) \\
\hline Raw mushroom & $20-$ & $22-94$ & (Koch et al., 2013) \\
\hline Cooked rice & $63-99$ & - & (Laparra et al., 2005) \\
\hline Cooked rice, white & & - & (Lee and Lee, 2017) \\
\hline Cooked rice, brown & & - & (Lee and Lee, 2017) \\
\hline Raw mushroom & $74-88$ & $86-97$ & (Llorente-Mirandes et al., 2016) \\
\hline Griddled and boiled mushroom & $77-89$ & $80-100$ & (Llorente-Mirandes et al., 2016) \\
\hline Rice (parboiled) & $59-99$ & - & (Signes-Pastor et al., 2012) \\
\hline Rice (nonparboiled) & $36-69$ & - & (Signes-Pastor et al., 2012) \\
\hline Cooked rice (parboiled) & $80-99$ & - & (Signes-Pastor et al., 2012) \\
\hline Cooked rice & $38-57$ & - & (Sun et al., 2012) \\
\hline Rice & $45-79$ & - & (Trenary et al., 2012) \\
\hline Raw rice & $62-93$ & $75-96$ & (Zhuang et al., 2016) \\
\hline Cooked rice & $38-67$ & $72-80$ & (Zhuang et al., 2016) \\
\hline
\end{tabular}


Table 3. Daily intake of tAs, iAs and health risk assessment of children in Bangladesh

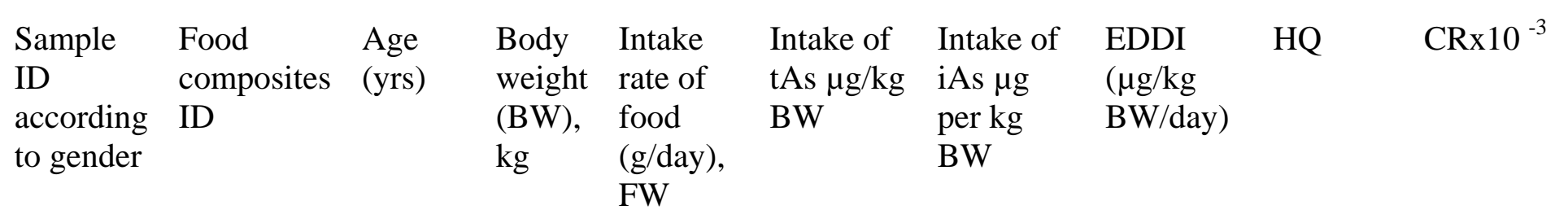

Exposed group

\begin{tabular}{|c|c|c|c|c|c|c|c|c|c|}
\hline Sh-B1 & $\mathrm{RC} 1$ & 5 & 16.4 & 315 & 7.59 & 6.24 & 6.0 & 20.08 & 9.0 \\
\hline Sh-B2 & $\mathrm{RC} 2$ & 12 & 33.4 & 563 & 2.56 & 2.32 & 2.4 & 8.14 & 3.6 \\
\hline Sh-B3 & $\mathrm{RC} 4$ & 14 & 32.9 & 401 & 2.05 & 1.71 & 1.8 & 5.97 & 2.7 \\
\hline Sh-B4 & RC5 & 7 & 17.1 & 263 & 2.44 & 1.96 & 2.3 & 7.68 & 3.4 \\
\hline Sh-B5 & RC5 & 13 & 43.7 & 319 & 1.16 & 0.93 & 1.1 & 3.64 & 1.6 \\
\hline Sh-B6 & RC5 & 3 & 13.3 & 176 & 2.10 & 1.68 & 2.0 & 6.61 & 2.9 \\
\hline Sh-B7 & RC6 & 3 & 13.1 & 148 & & 1.68 & 1.8 & 6.19 & 2.8 \\
\hline Sh-B8 & $\mathrm{RC} 8$ & 7 & 19.5 & 289 & 5.38 & 3.69 & 3.8 & 12.79 & 5.7 \\
\hline Sh-B9 & $\mathrm{RC} 8$ & 9 & 19.1 & 299 & 5.68 & 3.90 & 4.0 & 13.51 & 6.1 \\
\hline Su-B10 & $\mathrm{RC} 10$ & 8 & 21.2 & 218 & 3.81 & 3.19 & 3.1 & 10.52 & 4.7 \\
\hline $\mathrm{Su}-\mathrm{B} 11$ & RC11 & 7 & & 299 & 1.36 & 0.76 & 0.72 & 2.39 & 1.1 \\
\hline Su-B12 & $\mathrm{RC} 11$ & 13 & 35.1 & 331 & 1.38 & 0.77 & 0.73 & 2.43 & 1.1 \\
\hline Su-B13 & $\mathrm{RC} 11$ & & 38.5 & 348 & 1.33 & 0.74 & 0.70 & 2.32 & 1.0 \\
\hline Su-B14 & $\mathrm{RC} 12$ & 8 & 23.9 & 395 & 1.98 & 1.39 & 1.3 & 4.38 & 2.0 \\
\hline Su-B15 & $\mathrm{RC} 12$ & 4 & 16.2 & 281 & 2.07 & 1.46 & 1.4 & 4.59 & 2.17 \\
\hline Su-B16 & RC14 & 9 & 26.5 & 203 & 0.90 & 0.44 & 0.4 & 1.26 & 0.6 \\
\hline Sh-G1 & $\mathrm{RC} 1$ & 3 & 13.2 & 259 & 7.75 & 6.38 & 6.1 & 20.51 & 9.2 \\
\hline Sh-G2 & $\mathrm{RC} 2$ & 6 & 16.5 & 385 & 3.54 & 3.22 & 3.4 & 11.27 & 5.1 \\
\hline Sh-G3 & RC3 & 9 & 28.4 & 424 & 3.42 & 2.38 & 2.3 & 7.65 & 3.4 \\
\hline Sh-G4 & RC3 & 2 & 10.1 & 85 & 1.93 & 1.34 & 1.3 & 4.31 & 1.9 \\
\hline Sh-G5 & RC4 & 7 & 20.3 & 405 & 3.35 & 2.80 & 2.9 & 9.78 & 4.4 \\
\hline
\end{tabular}




\begin{tabular}{|c|c|c|c|c|c|c|c|c|c|}
\hline Sh-G6 & RC5 & 15 & 40.7 & 457 & 1.78 & 1.43 & 1.7 & 5.61 & 2.5 \\
\hline Sh-G7 & $\mathrm{RC7}$ & 3 & 12.8 & 232 & 4.93 & 3.94 & 3.9 & 13.10 & 5.9 \\
\hline Sh-G8 & RC9 & 14 & 31.8 & 355 & 1.85 & 1.47 & 1.4 & 4.82 & 2.2 \\
\hline Su-G9 & $\mathrm{RC} 10$ & 13 & 42 & 316 & 2.79 & 2.33 & 2.4 & 8.09 & 3.6 \\
\hline Su-G10 & $\mathrm{RC} 11$ & 11 & 56.2 & 489 & 1.28 & 0.71 & 0.7 & 2.24 & 1.0 \\
\hline Su-G11 & $\mathrm{RC} 12$ & 7 & 24.4 & 226 & 1.11 & 0.78 & 0.7 & 2.45 & 1.1 \\
\hline $\mathrm{Su}-\mathrm{G} 12$ & $\mathrm{RC} 12$ & 3 & 15.7 & 182 & 1.39 & 0.98 & 0.9 & 3.07 & 1.4 \\
\hline Su-G13 & $\mathrm{RC} 13$ & 2 & 9.9 & 171 & 2.90 & 1.71 & 1.2 & 4.09 & 1.8 \\
\hline Su-G14 & $\mathrm{RC} 14$ & 15 & 50.5 & 360 & 0.84 & 0.41 & 0.3 & 1.18 & 0.5 \\
\hline Su-G15 & $\mathrm{RC} 14$ & 11 & 29.9 & 251 & 0.98 & 0.49 & 0.4 & 1.39 & 0.6 \\
\hline Mean & & $8.2 \pm 4.2$ & $26 \pm 12$ & $304 \pm 106$ & $2.7 \pm 1.8$ & $2.0 \pm 1.5$ & $2.0 \pm 1.5$ & $6.7 \pm 5.1$ & $3.1 \pm 2.3$ \\
\hline Range & & $2-15$ & $10-56$ & $85-563$ & $0.8-8$ & $0.4-6$ & $0.3-6$ & $1-20$ & $0.5-9$ \\
\hline \multicolumn{10}{|c|}{ Unexposed group } \\
\hline Bh-G1 & $\mathrm{RC} 15$ & 11 & 47.2 & 356 & 0.09 & 0.09 & 0.08 & 0.3 & 0.1 \\
\hline Bh-G2 & $\mathrm{RC} 15$ & 11 & 46.6 & 4 & 0.10 & 0.09 & 0.08 & 0.3 & 0.1 \\
\hline Bh-B1 & $\mathrm{RC} 16$ & 6 & & 316 & 0.17 & 0.08 & 0.08 & 0.2 & 0.1 \\
\hline $\mathrm{Bh}-\mathrm{B} 2$ & $\mathrm{RC} 17$ & 7 & 25.4 & 323 & 0.16 & 0.15 & 0.09 & 0.3 & 0.1 \\
\hline Mean & & $8.7 \pm 2.6$ & $37 \pm 11$ & $337 \pm 21$ & $0.13 \pm 0.04$ & $0.10 \pm 0.03$ & $0.08 \pm 0.01$ & $0.3 \pm 0.03$ & $0.12 \pm 0.01$ \\
\hline Range & & $6-11$ & $25-47$ & $316-356$ & $0.1-0.2$ & $0.1-0.1$ & 0.07-0.09 & $0.3-0.3$ & $0.12-0.14$ \\
\hline
\end{tabular}

Note: $\mathrm{Sh}=$ Shahpur, $\mathrm{Su}=$ Sursoi, $\mathrm{Bh}=$ Bhelanagar, $\mathrm{B}=\mathrm{Boy} ; \mathrm{G}=$ Girl 